\title{
THE USE OF ENGLISH CLASSROOM GREETING AND CHARACTER BUILDING IN TK PELITA SARI DESA MAMBANG TABANAN
}

\author{
I.P.Y. Purandina \\ English Language Education, Sekolah Tinggi Agama Hindu Negeri Mpu Kuturan, Singaraja \\ e-mail: yogapurandina@sthnmpukuturan.ac.id
}

This study aims to determine activities of using English classroom greeting expressions in TK Pelita Sari, Desa Mambang, Tabanan, to find out perceptions of teachers and parents regarding development of English language skills at an early stage for the children who are influenced by habituation of this English classroom greeting activity, and to determine the positive value contained in English classroom greeting expressions on formation of children's characters. A qualitative descriptive method was employed using observation sheets and interview guides to children, teachers and parents. The results show that: first, the activity of using the English Classroom Greeting was a routine activity carried out every day by the children; second, teachers and parents perceived that the use of the expressions provided language experience for the children which resulted in positive development in speaking and listening in English. Third, there were two character values that seemed to develop along with the language experience in using English Classroom Expression, namely, friendly / communicative and social respect.

\section{Keywords: Character Building; English Classroom Greeting; English In Kindergarten}

\section{INTRODUCTION}

In this globalization era, the use of foreign languages, especially the use of English, is very important. In this era, it is possible for every individual to interact globally (Ushioda \& Dornyei, 2017). Global interaction here means that the interaction between regions involving countries or nations. So that the more rapid this interaction will cause business in various sectors, such as the economy, tourism, education, industry, etc. In this era, people are accustomed to communicating and interacting which is separated by great distances and different times (Carr, 2020).

This is also supported by advances in information technology which recently in the era of the industrial revolution 4.0 are progressing faster and faster. Every individual can access various information quickly without being limited by space and time, anytime and anywhere. Even with the current $4 \mathrm{G}$ internet speed it is possible to communicate live streaming without any signal problems etc. (Wang, 2016). However, this would be impossible if every individual in the world, especially in Indonesia, was unable to use English to communicate.

Recent data regarding the mastery of foreign languages, especially English in Indonesia, shows something of concern. Indonesia is ranked 61 out of 100 countries where English is a foreign language (EF, 2019). This English Proficiency Index is a research conducted by EF Global, where the mastery of English is still low. This is of course due to several factors such as the lack of habituation in using English, the lack of opportunities for students to be able to practice their English skills in the real world, and the lack of recognition of English from an early age (Menggo, Suparwa, \& Astawa, 2019).

At young age (in this case kindergarten age), English is sometimes considered not very important to be introduced or mastered. Parents are usually afraid to introduce English because they think English can damage children's recognition of their mother tongue. In fact, the introduction of foreign languages, in this case English, is best done from an early age (Hussain et al., 2015). There are many experts agree that knowing the language as an indigenous person before the age of ten helps children to talk correctly and fluently. Therefore, whatever the earlier children are familiar with foreign language, he has a greater opportunity to speak skills (Crowe \& Guiberson, 2020).

In addition, acquiring a second language after the age of three is called successive 
bilingualism where the acquisition of a second language of this type is actually the same patterns as acquiring the first language with one word utterance, two words then many words so it doesn't really matter if the acquisition of the second language starts in early childhood (Loewen \& Sato, 2018). Children who speak two or more languages appear to be able to distinguish between two different systems of language use (Paradis, 2019). As in TK Pelita Sari, Desa Mambang, Tabanan, which has designed its learning by inserting a second language, in this case English as an introduction to English which will be useful for life.

Young children can be introduced to the second language, namely English since they were considered at the perfect age where their Language Acquisition Device could require the new language naturally. In Indonesia, at the level of Early Childhood Education (PAUD), English has actually been included in the learning curriculum. However, practice in the field is still not optimal, as has happened in various PAUD education units, both Kindergarten $B, A$, and Play Group, especially in suburban or rural areas, which still shows the lack of learning English itself.

Early childhood teachers introduce English lesson to the children by introducing English from the basic level such as greetings, names of days, animals, etc. The learning strategy is a bit more unique, such as by singing together, telling stories, or playing various games (Widiyanti et al., 2018). Children do have to be conditioned in such a way that learning occurs in threat-free atmosphere. Learning context is very important so that they will find it easier to recognize English as a second language (Yusuf et al., 2017). In addition, English should be introduced through habituation, such as saying greetings in English.

This greeting is usually done at the beginning of learning and when learning ends. Greetings are an expression made by someone to greet each other. This activity is something that is commonly done as a social being to initiate interactions with others (Shields-Lysiak et al., 2020). In TK Pelita Sari, Desa Mambang, children are accustomed to saying greetings in three languages, namely, Indonesian, Local Language (Balinese), and English every day. In addition to improving English language skills, the initial stage of greeting is also intended for the formation of children's character.

In Pelita Sari Kindergarten, Mambang Tabanan Village, children were observed to have made efforts to learn English as an initial introduction through greetings expressions so that it allows the development of children's English language skills. In addition, the activity of saying greetings in English makes it possible to have a relationship with character building.

This study attempts to identify activities of using English classroom greeting expressions in TK Pelita Sari, Desa Mambang, Tabanan, to find out perceptions of teachers and parents regarding development of English language skills at an early stage for the children who are influenced by habituation of this English classroom greeting activity, and to determine the positive value contained in English classroom greeting expressions on formation of children's characters.

\section{RESEARCH METHOD}

This research is a qualitative descriptive study. The data were obtained using a qualitative approach in which more emphasis was placed on the quality of the data obtained regarding the use of greetings as an initial introduction to English at TK Pelita Sari, Desa Mambang, Kecamatan Selemadeg Timur, Tabanan. The quality of the data here is in accordance with the social situation which consists of three elements, namely place, actor, and activity, and the researcher directly observes in depth the social phenomenon or situation that occurs in the field. So that researchers have a central role in this study (Creswell \& Creswell, 2017).

In this study, researchers analyzed the use of classroom greeting as an initial introduction to English as a foreign language in TK Pelita Sari Mambang, Desa Mambang, Tabanan. Classroom observation was conducted by means of observation sheet instrument to collect data on the language experinces the teacher provided for the students to start learning to use the foreign language. The classes observed were in the form of virtual or online classes, which was organized via WhatsApp. Besides that, an interview guide was also used to obtain data on parents' perceptions of children's English development. The purpose of this instrument is to obtain data that can answer research problems, namely the 
habit of using greetings in class at the beginning and end of learning, as well as the effect of using classroom greeting expressions on English language skills at an early stage for children. To find out the value contained in the classroom greeting expression on the formation of children's characters, observation and interview was also conducted to specifically find the character values that develop as the results of using expressions of greetings.

In general, the researcher is the main instrument in this study. The researcher analyzes the data obtained through direct observation and on learning in the class lesson of the children of TK Pelita Sari, Desa Mambang, Tabanan. The group is in the form of an online class that uses the WhatsApp application. The researcher directly joins the WhatsApp group with the teacher, students who are accompanied by their parents. Then, an interview guide was also used to interview the teacher and parents. Interview section conducted via chat and call on WhatsApp to teachers and parents. These instruments have been validated by experts in the field of teaching English and are the right instruments to obtain data in this qualitative research, especially in conducting qualitative descriptive research methods. This instrument plays an important role in obtaining data through the process of observing and obtaining data.

To get good and precise data, it is necessary to obtain valid and reliable data. So that the data obtained should be cross-checked and repeated so that valid data is obtained which is called Triangulation data (Connelly, 2016). Data triangulation is an approach or way to obtain accurate data by using various data collection techniques. In this research, this has been done by using observation and interview guide. These were expected to increase the trustwortiness of the data (Roulston, 2018).

In analyzing the data, the researcher used three concepts or data analysis techniques introduced by Miles-Hubermans. The three concepts of this approach are firstly data reduction which is directly carried out on collecting data, secondly data display (data display), and the third is Data verification / Drawing cloncussion (Sugiono, 2019). This analytical approach is an activity that is carried out directly which contains the process of investigating the problem or phenomenon that occurs. Once the data is obtained, it will be directly analyzed as a form of the investigation process. Analyzing the data here is carried out in an interactive and simultaneous way until all problems in this research are answered or a solution is obtained. Data reduction is done very carefully where only the necessary data is taken according to the problem research. The data in question is of course in accordance with the The Use of Classroom Greeting Expression as English Introduction at TK Pelita Sari Desa Mambang Tabanan in the data will be discarded or in other words discarded.

\section{FINDINGS AND DISCUSSION}

This research was conducted for three months with direct observation through online classes during the COVID-19 pandemic. In general, researchers managed to collect comprehensive data as the bases to answer the problems of this study. There are three findings obtained that are consistent with the research problems in this study.

First, the use of greetings in the classroom using English for the children of TK Pelita Sari, Desa Mambang, Tabanan is an obligation. Students say greetings at the beginning and end of the lesson which is guided by the teacher. The teacher says greetings first at the beginning of the lesson in three languages, namely Local Language (Balinese), Indonesian, and also English. Because they are still in the state of the COVID-19 pandemic, students are learning online from home using the WhatsApp application accompanied and assisted by their parents.

The class takes place on the WhatssApp group which replaced the face to face class interaction. The teacher used various greeting expressions which were replied by the students greeted the teacher back. There was a great enthousiasm observed which indicate that children felt comfortable to experience with English language use. Greetings at the beginning of the lesson make the atmosphere more lively and cheerful. This greeting is sometimes transformed into the forms of a song or poem, or other forms of very entertaining rhymes. Then the teacher opens the lesson by reviewing the next lesson and continues with today's lesson by linking a song or story to the lesson. 
At the end of the lesson the children returns to giving greetings which are guided by the teacher in three languages every day. Then say thank you for the lesson given by the teacher on that day. Just like the greeting at the beginning of the lesson, at the end of the lesson the teacher usually inserts a greeting in the form of a song, by changing the song with some lyrics about saying greetings. With songs, children usually feel more enthusiastic about learning, so they are motivated and excited even at the end of the lesson.

English greeting activity at TK Pelita Sari, Desa mambang, Tabanan are routinely done every day. Besides being carried out every day on Friday (English Day), where the introduction of English is more optimally introduced on that day. Not only greetings but other simple introduction to English vocabulary. Also given are various English language learning media such as Youtube videos about English songs and stories. So that the use or pronunciation of greetings in English is getting stronger or better with this advanced introduction to English.

The greetings in English that are usually said by the children of TK Pelita Sari Mambang are "Hello", "Hi", "Good Morning", "How are You", "How do you do". The responses from these expressions are "Hi", "Good Morning", "I am fine, thank you", "How do you do". At the end of the lesson they usually use leave taking expressions such as "Nice to meet you", "See you", "See you tomorrow", "Thank you". Then the response to leave taking expression is "Nice to meet you too", "See you too", "You are welcome".

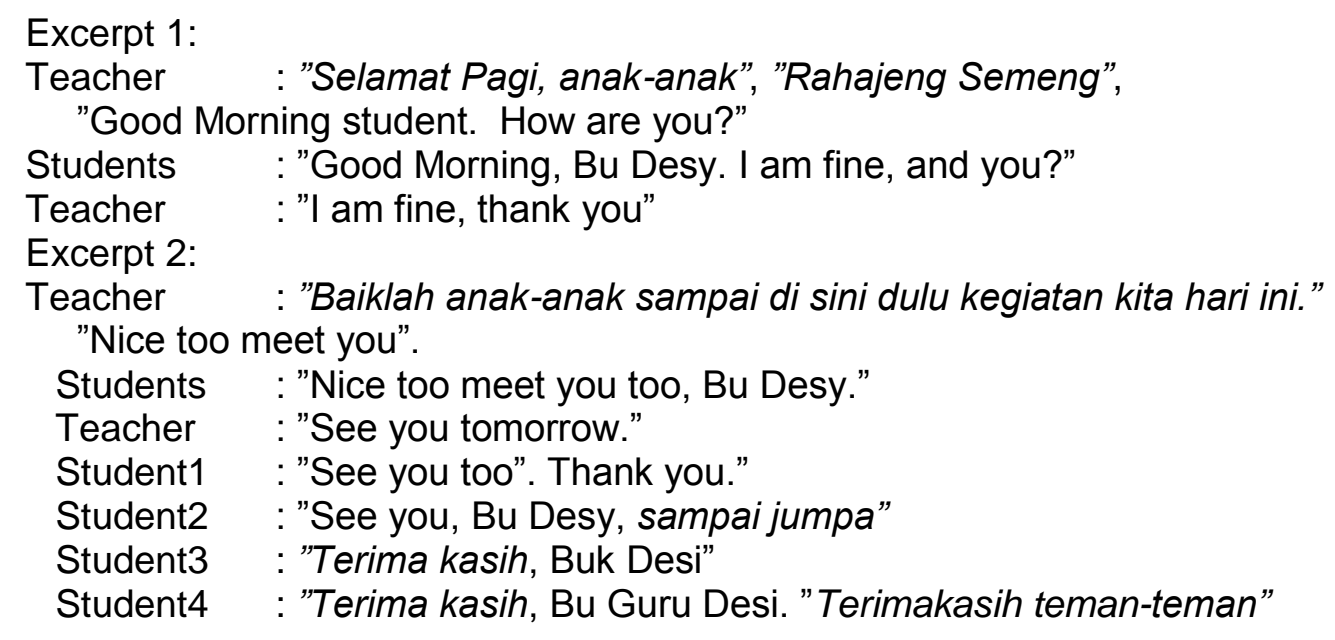

Excerpt 1 and 2 above are direct conversations in online classes via WhatsApp group that occur every day. The researcher directly observed the conversation between the teacher and the student and the student and the student. In Excerpt 1, it contains conversations between teachers and students at the beginning of learning. The teacher gives greetings in the form of greetings in English. There, the children were seen enthusiastically responding to the greetings uttered by the teacher in English. Excerp 2 contains a leave taking expression at the end of learning activities. Indeed, not all of the children were able to respond to the teacher's farewell, but they were already very enthusiastic in responding to the greeting.

So that the habit or routine of using this greeting has been very well done by teachers and PAUD students at TK Pelita Sari, Desa Mambang, Tabanan. Building this habit is very good considering children are good imitators at their age (Suhana, 2018) (Rustan, 2020). So that what they are accustomed to will do well continuously. This greeting activity is very good to be used continuously to familiarize the child with knowing and greeting everyone.

Second, the findings are regarding the perceptions of teachers and parents about the development of English skills for the children at TK Pelita Sari, Desa Mambang, Tabanan. This result is the result of data analysis of interviews with teachers and parents of the children of TK Pelita Sari, Desa Mambang, Tabanan. It is revealed that the English development of the children of TK Pelita Sari Desa Mambang, Tabanan has increased, especially in speaking and listening. For example, the habit of using greetings in English at 
school and even at home (Ashari, 2017).

Then, the child responds quickly if someone greets in English by saying a reply. This can be seen when teachers or school residents give greetings in English, the children will quickly respond and are very enthusiastic about showing respect for teachers and other school members. Likewise at home every time someone greets a child, the child will respond well to the English greeting that is delivered to the child. This is an extraordinary development as an initial introduction to English for the children of Pelita Sari Kindergarten, Mambang Village, Tabanan.

The development of children's ability to speak in English, of course, is because the English Classroom Greeting is continuously spoken, so that children become accustomed to saying these greetings. Therefore, the child's speaking ability has developed a little, namely being able to say greetings in English. Likewise, the ability to listen, the children heard or read messages on the WhatsApp group regarding the English Classroom Greeting, they were getting used to responding and replying to these greetings. As an initial introduction to English, this activity is very good, to build children's interest in further introduction to English.

Third, by getting children to say greetings and responding to greetings, it will certainly form a positive character for the children. There are several character values that depend on the classroom greeting activity. The character values contained in it will be presented in the following table.

Table 1. Character Values Contained on English Classroom Greeting

\begin{tabular}{lll}
\hline English & Respond & Character Values \\
Classroom & & \\
Greeting & & Friendly/Communicative
\end{tabular}

\begin{tabular}{ll}
\hline $\mathrm{Hi}$ & $\mathrm{Hi}$ \\
&, Friendly/Communicative \\
& Social Respect \\
\hline
\end{tabular}

\begin{tabular}{ll}
\hline Hello Hello & , Friendly/Communicative \\
& Social Respect
\end{tabular}

\begin{tabular}{|c|c|c|}
\hline Good Morning. & Good Morning. & $\begin{array}{l}\text { Friendly/Communicative } \\
\text { Social Respect }\end{array}$ \\
\hline How are you? & I am fine. & $\begin{array}{l}\text { Friendly/Communicative } \\
\text { Social Respect }\end{array}$ \\
\hline How do you do? & How do you do. & $\begin{array}{l}\text { ' Friendly/Communicative } \\
\text {, Social Respect }\end{array}$ \\
\hline Nice to meet you. & $\begin{array}{l}\text { Nice to meet you } \\
\text { too. }\end{array}$ & $\begin{array}{l}\text { ' Friendly/Communicative } \\
\text {, Social Respect }\end{array}$ \\
\hline See you. & See you too. & $\begin{array}{l}\text { Friendly/Communicative } \\
\text {, Social Respect }\end{array}$ \\
\hline $\begin{array}{l}\text { See you too } \\
\text { tomorrow. }\end{array}$ & See you. & $\begin{array}{ll}\text {, } & \text { Friendly/Communicative } \\
\text {, Social Respect }\end{array}$ \\
\hline Good bye. & Bye. & $\begin{array}{l}\text { ' Friendly/Communicative } \\
\text {, Social Respect }\end{array}$ \\
\hline
\end{tabular}

Based on the table above, the characters that emerge from the use of English Classroom Greeting are Friendly / Communicative and Social Respect. These character values are part of the 18 characters echoed by the government through the Ministry of Education and Culture (Itjen Kemendikbud, 2020) (Peraturan Menteri Pendidikan Dan Jurnal Pendidikan Bahasa Inggris Indonesia | 16 
Kebudayaan Republik Indonesia Nomor 20 Tahun 2018. Penguatan Pendidikan Karakter Pada Satuan Pendidikan Formal. 7 Juni 2018. Lembaran Negara Republik Indonesia Tahun 2018 Nomor 194., 2018). Giving greetings does show a good behavior to show or form a friendship where greetings are a conversation starter between individuals as social beings. In addition, greetings show social respect to others by greeting and trying to build good relationships with others (Purandina \& Winaya, 2020).

These two character values are very positive in shaping the character of a child at his age. Children will get used to being friendly / communicative to anyone and anywhere. Trying to establish a good and warm impression on everyone, make friends so that a good relationship can be established. Likewise, Social Respect is very good when shown to others. Children will get used to showing their concern for everyone, as social creatures who always need other people in this life. These two character values will also stimulate other character values contained in the 18 characteristics of the Indonesian Nation, instilled by the government.

This character education is the most important thing, not only giving children knowledge in the form of theory but also in the form of moral education in the form of morals which is called character education. Character education from an early age will certainly be able to positively shape children's character to show good character. This good character or behavior will later make it easier for children to establish relationships with other individuals so as to create harmony in a social community both in family, school, and society.

The habit of saying classroom greeting is of course the first step in building character for children so that it can continue to be applied in the family environment and the community environment. During the COVID-19 pandemic, this is a very good thing to do, where children spend more time at home. Children do distance learning, namely through online classes, so that what is given to the online class can continue later in the family environment and become positive things that can be done by children.

\section{CONCLUSION AND SUGGESTIONS}

In short, this study has found answers to the three problems in this study in the form of research questions that have been previously described. First, the English classroom greeting activity by the children of TK Pelita Sari, Desa Mambang, Tabanan is a routine that is carried out every day, at the beginning and at the end of the lesson. In TK Pelita Sari, Desa Mambang, Tabanan actually uses three language greetings every day, namely Balinese, Indonesian, and English. Second, the perceptions of teachers and parents on the development of children's English skills are very good when children are introduced and accustomed to saying greetings in English. Children often say and respond to excess greetings in English. Both at school and at home children are becoming increasingly trained in speaking and listening skills. Third, the activity of saying this greeting also contains positive values so that it can stimulate the formation of children's character. There are two character values contained such as friendly / communicative and social respect. Thus this research, hopefully in the future research on English education related to character education for children can be further investigated by other researchers.

\section{ACKNOWLEDGEMENT}

In this part, the researchers would like to express their highest gratitude to the Chairman of STAHN Mpu Kuturan Singaraja, the Head of the Dharma Acarya Department, and the Head of the PGPAUD Study Program who always motivates lecturers to always carry out the Tri Dharma of Higher Education, especially in the research field. The researchers also did not forget to thank the Principal, Teachers, Parents of Students, and the children of TK Pelita Sari, Desa Mambang, Tabanan, who have always helped provide the data for this research.

\section{REFERENCES}

Ashari. (2017). Habitual action on English learning: study at YPRU Guyangan Trangkil Pati [UIN Walisongo]. http://eprints.walisongo.ac.id/8411/

Carr, N. (2020). The Shallows: How the Internet Is Changing the Way We Think, Read and Remember ed.). Atlantic

Books. 
https://books.google.co.id/books?hl=en\&lr=\&id=AsZ1R3|96FEC\&oi=fnd\&pg=PT9\&dq=t he+emergence+of+the+internet+and+smartphones+that+have+changed+human+life $+c$ rucially.+This+change+can+be+seen+from+the+way+of+thinking,+lifestyle,+and+how+ people+socialize+in+vari

Connelly, L. M. (2016). Trustworthiness in qualitative research. MedSurg Nursing, 25(6), $435+$.

Creswell, J. W., \& Creswell, J. D. C. (2017). Reseach Design; Qualitative, Quantitative, Mix Methodes Approaches (1st ed.). SAGE Publications Inc.

Crowe, K., \& Guiberson, M. (2020). Professionals' Perspectives on Supporting Deaf Multilingual Learners and Their Families. The Journal of Deaf Studies and Deaf Education. https://doi.org/https://doi.org/10.1093/deafed/enaa025

EF. (2019). EF EPI ENGLISH PROFICIENCY INDEX. https://www.ef.co.id/epi/

Hussain, A., Altaf, S., \& Scholars, D. (2015). Krashen's Theory of Second Language Acquisition: A Practical Approach for English Language Classrooms. International Journal of Innovative Knowledge Concepts, 1(1), 17-21.

Itjen Kemendikbud. (2020). Dimensi Pendidikan Karakter. Inspektorat Jendral Kemendikbud. https://itjen.kemdikbud.go.id/public/post/detail/dimensi-pendidikan-karakter

Menggo, S., Suparwa, IN., \& Astawa, IG. (2019). Hindering Factors in The Achievement of English Communicative Competence in Tourism Academy Students.

Aksara 31(1), 137-152 https://doi.org/10.29255/aksara.v31i1.235.137-152

Peraturan Menteri Pendidikan dan kebudayaan Republik Indonesia Nomor 20 Tahun 2018. Penguatan Pendidikan Karakter pada Satuan Pendidikan Formal. 7 Juni 2018. Lembaran Negara Republik Indonesia Tahun 2018 Nomor 194., (2018).

Loewen, S., \& Sato, M. (2018). Interaction and instructed second language acquisition. Language Teaching, 51(3), 285-329. https://doi.org/10.1017/S0261444818000125

Paradis, J. (2019). English second language acquisition from early childhood to adulthood: The role of age, first Language, cognitive, and input factors. Proceedings of the 43rd Boston University Conference on Language Development, 11-26. https://www.ualberta.ca/linguistics/cheslce

Purandina, I. P. Y., \& Winaya, I. M. A. (2020). Pendidikan Karakter di Lingkungan Keluarga Selama Pembelajaran Jarak Jauh pada Masa Pandemi COVID-19. Cetta: Jurnal IImu Pendidikan, 3(2), 270-290. https://doi.org/10.37329/cetta.v3i2.454

Roulston, K. (2018). Triangulation in qualitative research. QualPage. https://qualpage.com/2018/01/18/triangulation-in-qualitative-research/

Rustan, E. (2020). Stimulation of child's sexual imitation behavior through Neurolinguistic programming. Jurnal Konseling Dan Pendidikan, 8(2), 61. https://doi.org/10.29210/136300

Shields-Lysiak, L. K., Boyd, M. P., lorio, J. P., \& Vasquez, C. R. (2020). Classroom greetings: More than a simple hello. Iranian Journal of Language Teaching Research, 8(3), 41-56.

Sugiono. (2019). Metode Penelitian Kualitatif. Afabeta.

Suhana, M. (2018). Influence of Gadget Usage on Children's Social-Emotional Development. 169(Icece 2017), 224-227. https://doi.org/10.2991/icece-17.2018.58

Ushioda, E., \& Dornyei, Z. (2017). Beyond Global English: Motivation to Learn Languages in a Multicultural World: Introduction to the Special Issue. The Modern Language Jurnal, 101(3), 451-454. https://doi.org/https://doi.org/10.1111/modl.12407

Wang, J. (2016). Enlightenment from the Innovative Application of 4G Communication Technology in the Mobile Library. 2016 International Conference on Smart City and Systems Engineering (ICSCSE). https://doi.org/10.1109/ICSCSE.2016.0050 
Widiyanti, R., Rasyid, Y., \& Darmahusni, D. (2018). The Use of English Introduction Language in Learning in Montessori Indonesia Preschool. Ijlecr - International Journal of Language Education and Culture Review, 4(2), 168-171. https://doi.org/10.21009/ijlecr.042.21

Yusuf, Q., Asyik, A. G., Yusuf, Y. Q., \& Rusdi, L. (2017). Listen, do, repeat, understand and remember: Teaching English to very young children in Aceh. Iranian Journal of Language Teaching Research, 5(2), 113-132. 